\title{
Management of hazard of flooding in arid region urban agglomeration using HEC-RAS and GIS software: The case of the Bechar's city
}

\author{
Abdelghani BEKHIRA ${ }^{\text {1) ABCDEF } ₫}$, Mohammed HABI ${ }^{2)}$ ADF, \\ Boutkhil MORSLI ${ }^{3)}$ A
}

1) orcid.org/0000-0003-1743-9557; Abou Bakr Belkaid University, Faculty of Technology, Department of Hydraulic, P.O. Box 230,
13000 Tlemcen, Algeria; e-mail: bekhiraghani@gmail.com
2) Abou Bakr Belkaid University, Faculty of Technology, Department of Hydraulic, Tlemcen, Algeria; e-mail: moha.habi@gmx.de
3) orcid.org/0000-0002-7302-7648; National Institute for Forest Research in Tlemcen, Algeria; e-mail: morsli_boutkhil@yahoo.fr

For citation: Bekhira A., Habi M., Morsli B. 2019. Management of hazard of flooding in arid region urban agglomeration using HECRAS and GIS software: The case of the Bechar's city. Journal of Water and Land Development. No. 42 (VII-IX) p. 2132. DOI: $10.2478 /$ jwld-2019-0041.

\begin{abstract}
During the last few years, the City of Bechar in Algeria has witnessed some extreme events, such as the great flood of the year 2008 in which an exceptional amount of rain was recorded with a flow rate of $830 \mathrm{~m}^{3} \cdot \mathrm{s}^{-1}\left(h_{\mathrm{water}}=4 \mathrm{~m}, b=200 \mathrm{~m}\right)$; similar flooding also occurred in 2012 and 2014. The problem is that most of the City of Bechar has an urban sprawl that extends to the banks of Wadi Bechar, which represents a huge risk for the lives of the inhabitants of the region. The present work aims to assess the flood risk through flood hazard mapping. This method consists in determining the flow rates for the return periods of 25 years $\left(Q_{25}=388.6 \mathrm{~m}^{3} \cdot \mathrm{s}^{-1}, h_{\text {water }}=3.5 \mathrm{~m}, b=200 \mathrm{~m}, S_{\text {spot }}=55.35 \mathrm{ha}\right), 50$ years $\left(Q_{50}=478.3 \mathrm{~m}^{3} \cdot \mathrm{s}^{-1}\right.$, $\left.h_{\text {water }}=5 \mathrm{~m}, b=200 \mathrm{~m}, S_{\text {spot }}=66.48 \mathrm{ha}\right)$ and 100 years $\left(Q_{100}=567.3 \mathrm{~m}^{3} \cdot \mathrm{s}^{-1}, h_{\text {water }}=7 \mathrm{~m}, b=200 \mathrm{~m}, S_{\text {spot }}=133 \mathrm{ha}\right)$. For this, it is necessary to adjust the flow rates using Gumbel law along with some computer supports such as HEC-RAS, HEC-GeoRAS and ArcGis for mapping the event. Finally, this work enables us to determine the zones exposed to risk of flooding and to classify them according to the flood water height.
\end{abstract}

Key words: arid zones, climate change, flood, mapping, water resources

\section{INTRODUCTION}

Human life is based on the exploitation of natural resources. Unfortunately, the methods generally used are often not the best ones because they are not respectful towards nature.

The random exploitation of these resources very often leads to negative impacts on the environment, which results in climate change and natural disasters that are mostly unexpected [BEKHIRA et al. 2014; 2018; HOEGH-GULDBERG, BRUNO 2010; SCHMIDT et al. 2013]. This could even endanger lives.

Among the extreme weather events that are worth mentioning are floodings that have always existed throughout times. Ancient civilizations regarded them as divine wrath. This plague of floods is in perpetual growth due to climate change [KURIATA-POTASZNIK, SZYMCZYK 2016]; it always comes unexpectedly and threatens the entire world, particularly the underdeveloped countries which in general do not have the means to deal with it.

The watershed of Wadi Bechar is one of the most affected areas by floods. The flooding of October 2008 is considered as the largest (Photo 1); it was caused by the exceptional heavy rainfall received during that month. These strong inundations caused material and human damage, with significant socio-economic impacts on the agglomerations and populations around Wadi Bechar. The consequences of these floods were as follows: 8 people dead, 506 families affected, and 7677 head of cattle washed away by floodwaters [MERZOUGUI et al. 2014]. 

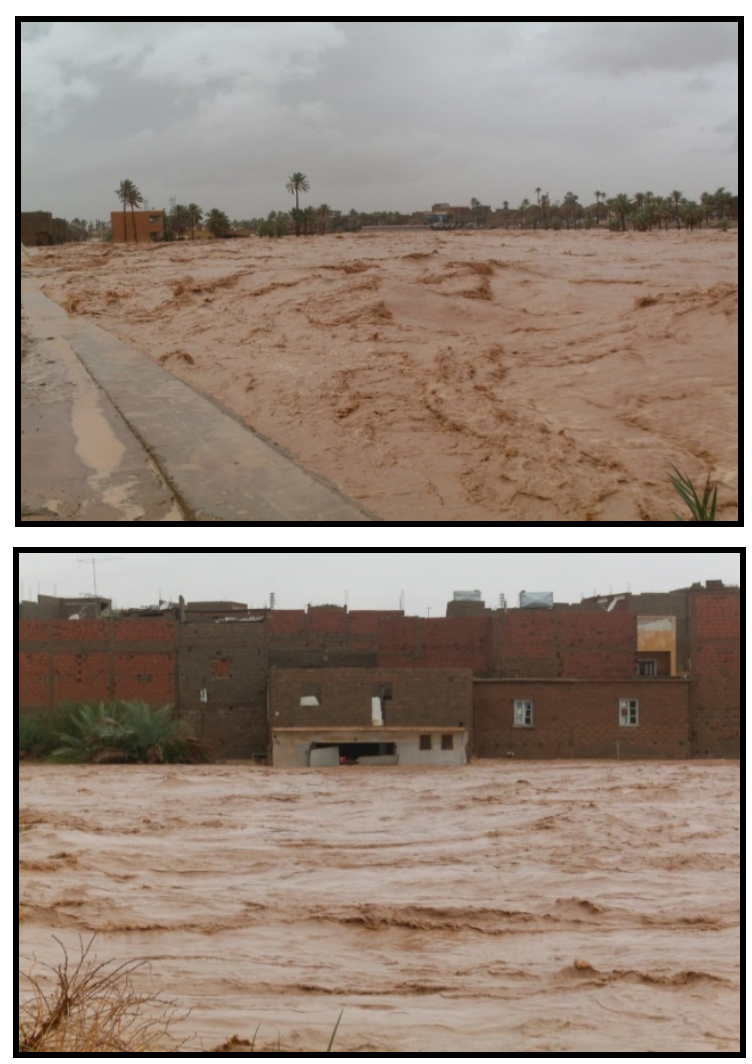

Photo 1. Height of water in Wadi Bechar during the 2008 floods (phot. A. Bekhira)

In the past, people were not so interested in flood events in desert areas because these zones were considered as arid zones where rainfall is scarce. However, today it is easy to see that desert areas suffer the most from the risks of flooding due to climate change [BASAHI et al. 2016]. This represents a real threat to lives because of the growing number of houses and agricultural activities installed on the banks of rivers where access to water resources is easier. This is especially true for Wadi Bechar around which a large number of people have settled down. It is worth mentioning that the source of flood risks in the town of Bechar comes mainly from Wadi Bechar when its waters overflow.

The mapping of flood vulnerability in the entire city of Bechar requires prior knowledge of the hydrology and topography of Wadi Bechar.

In order to be able to model water flows, it is first required to master the computer tool. For this, it was decided to choose the one-dimensional models HEC-RAS and HEC-GeoRAS which are free software that are available and easy to handle; the software ArcGis was also selected as a Geographic Information System (GIS) tool to represent floods in map form [ATALLAH et al. 2018].

The HEC-RAS models have been tested on a wide variety of watercourse [DERDOUS et al. 2015; HAGHIZADEH et al. 2012; PATEL, GUNDALIYA 2016; PARHI et al. 2012; PrafulKumar et al. 2011; XIONG 2011; YAKTI et al. 2018].

The data needed for this hydraulic modelling are the flows resulting from the hydrological study, the geometry of the watercourse that crosses the city of Bechar as well as the longitudinal slope and the roughness of the bed and banks in the various calculation points [BOUZAHAR et al. 2018].

The digital terrain model (DTM) was established with the help of a topographic survey that is $17000 \mathrm{~m}$ long and $300 \mathrm{~m}$ wide which was realized during this work. The geometric levelling was also performed for the purpose of ensuring perfect accuracy in hydraulic modelling as well as in map development. This modelling aims to represent schematically a real system of free-surface flow. For this, it is necessary to have flows that correspond to different time steps for flood vulnerability mapping.

This work showed that floods have also become a real danger which represents a great risk for the City of Bechar and its inhabitants. They must be seriously taken into account in the development and planning programs of the wilaya, by identifying the areas at risk and classifying them according to the height of floodwaters in order to better control the flow of rivers and reduce the impacts of this natural disaster on the different aspects of people's daily lives. Finally, this work will certainly help to know the impact of this natural event on the area around Wadi Bechar and also on various human and economic resources; it should also assist the local authorities to take the most appropriate measures and make the best decisions.

\section{MATERIALS AND METHODS}

\section{DATA}

There are several weather stations in the Wilaya of Bechar (Tab. 1); however, the study area has low coverage in climatic stations.

Table 1. Characteristics of weather stations of the city of Bechar

\begin{tabular}{|c|c|c|c|c|c|}
\hline Station kind & Code & Longitude & Latitude & $\begin{array}{c}\text { Altitude } \\
\text { (m a.s.1.) }\end{array}$ & Period \\
\hline $\begin{array}{c}\text { Hydrometric } \\
\text { (ANRH) }\end{array}$ & $\begin{array}{c}1301 \\
32\end{array}$ & $31^{\circ} 37^{\prime} 00^{\prime \prime} \mathrm{N}$ & $02^{\circ} 14^{\prime} 00^{\prime \prime} \mathrm{W}$ & 772 & $\begin{array}{c}1985- \\
2009\end{array}$ \\
\hline $\begin{array}{c}\text { Meteorolog- } \\
\text { ical (ONM) }\end{array}$ & $\begin{array}{c}1301 \\
13\end{array}$ & $31^{\circ} 35^{\prime} 53^{\prime} \mathrm{N}$ & $02^{\circ} 13^{\prime} 32^{\prime} \mathrm{W}$ & 774 & $\begin{array}{c}1968- \\
2010\end{array}$ \\
\hline
\end{tabular}

Source: ANRH [2011].

Rainfall data were provided by the National Office of Meteorology (Fr. Office National de la Météorologie ONM) from the only meteorological station in the region of Bechar, for the period extending from 1968 to 2010; additional data on water flows were obtained from the hydrometric station of the National Agency for Hydraulic Resources (Fr. Agence Nationale des Ressources Hydrauliques - ANRH) for the period between 1985 and 2010.

Regarding the climate study of the watershed of Wadi Bechar, it was decided to use the data recorded by the local climatic station.

\section{METHODS}

The method used in the present work consisted in conducting a hydrological study at first. The statistical analysis was carried out using the Gumbel law which was employed in the prevention of floods from Wadi Bechar, cor- 
responding to the return periods of 25 years, 50 years and 100 years.

The first part of this study was to carry out a statistical analysis of the hydrometric data. In the second phase, a hydraulic study was performed in order to be able to determine the levels of water corresponding to the flows mentioned above. To do this, the results of the hydrological study combined with the geometry, slope and length of Wadi Bechar were used as input data of the hydraulic model HEC-RAS for the purpose of obtaining the corresponding runoff. The first step was therefore to manually digitize the central line of Wadi Bechar in shapefile format, using the geometry preprocessor of the HEC-GeoRAS software with the background aerial images as well as the digital topographic maps in order to determine the location of Wadi Bechar.

The rest of the shapefiles, such as river banks, flow lines and transversal sections, which are needed for the HEC-GeoRAS software, were also created. The only shapefile imported into the program HEC-RAS is the median line of the river. It should be noted that some sections were modified to avoid crossover with the other sections.

Then, the model was run and the calculated surface water altitude was exported into the program GIS in the xml format. Afterwards, the results obtained were processed using the HEC-GeoRAS mapping tools. The first step in the mapping process by HEC-GeoRAS was to convert the HEC-RAS results into the GIS format. The delimitation polygon was determined first, and then the water depth was calculated. After that, the flood extent boundary line for each water surface elevation was also identified. In the end, the results of the hydraulic modelling (water depth for each flow) were presented in the form of hazard maps using the ArcGis mapping tool.

\section{GEOGRAPHIC CONTEXT}

The Wilaya of Bechar is one of the largest provinces in southern Algeria, as shown in Figure 1; it is located in the southwestern region of the country. The City of Bechar is located at an altitude of $807 \mathrm{~m}$, a longitude of $02^{\circ} 13^{\prime} 00^{\prime \prime}$ $\mathrm{W}$ and a latitude of $31^{\circ} 38^{\prime} 00^{\prime \prime} \mathrm{N}$. It is limited:

- to the East by the Wilaya of Adrar,

- to the West by the Kingdom of Morocco,

- to the North by the Wilayas of Naâma and El Bayadh,

- and to the South by the Wilayas of Tindouf and Adrar [BENARADJ et al. 2012].

\section{GEOLOGICAL CONTEXT}

The region of Bechar is situated in the northwestern part of the Algerian Sahara; its geology is represented by lands ranging from Carboniferous to Quaternary.

The terrain consists of various sets of ground levels and different formations, namely:

- Jebel Grouz, Chebket Charef and Chebket Fendi which belong to the Lower, Middle and Continental Jurassic;

- Djebel Antar, Djebel Bechar and Djebel Mezzarif, which are largely Visean with edges and snags consisting of Namurian and Westphalian;

- the Reg and Hamada below the heights mostly consist of recent Quaternary with dune deposits resting on the Quaternary;

- the Zousfana valley that mainly consists of alluvium.

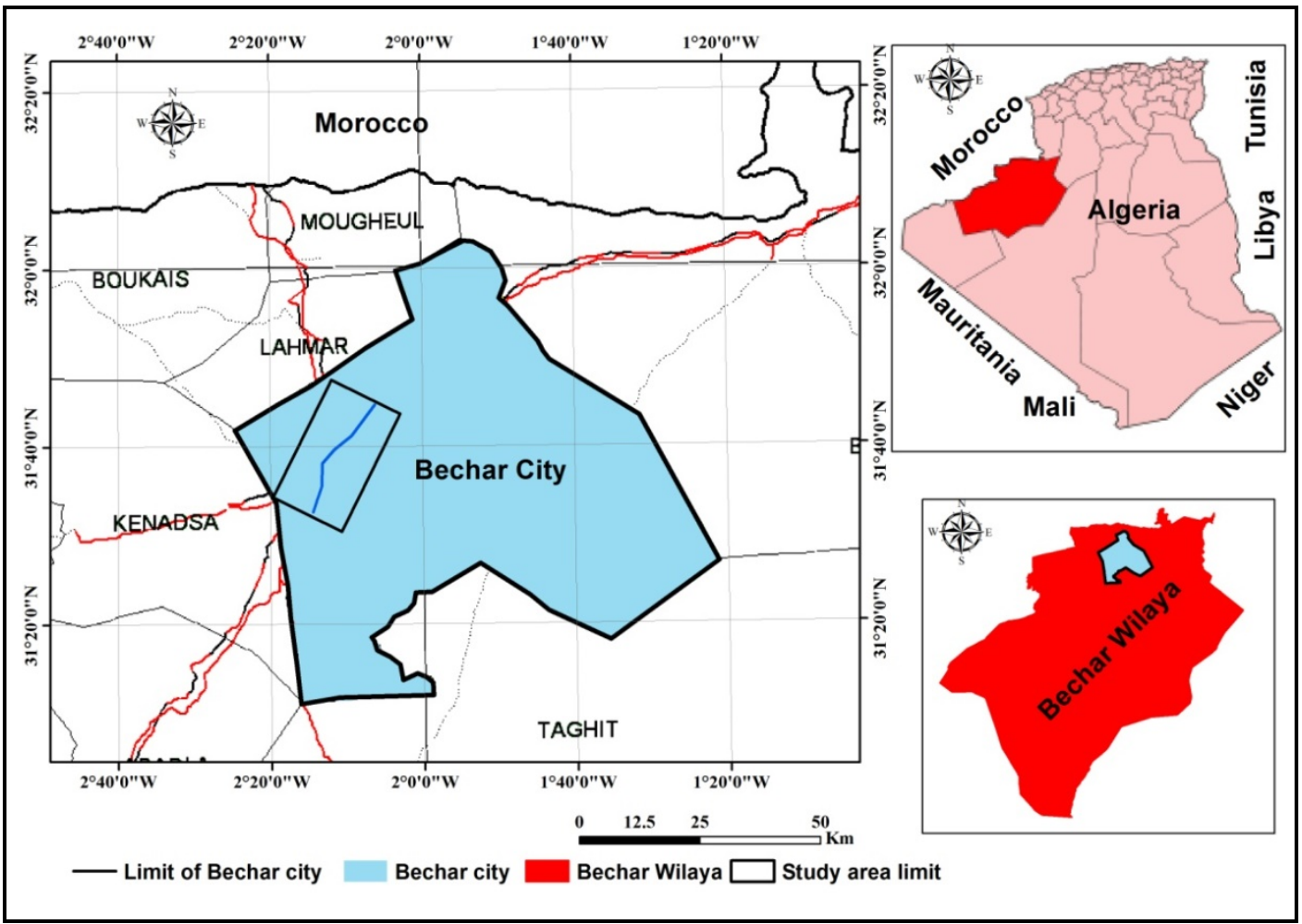

Fig. 1. Map showing the geographical location of Bechar; source own elaboration 


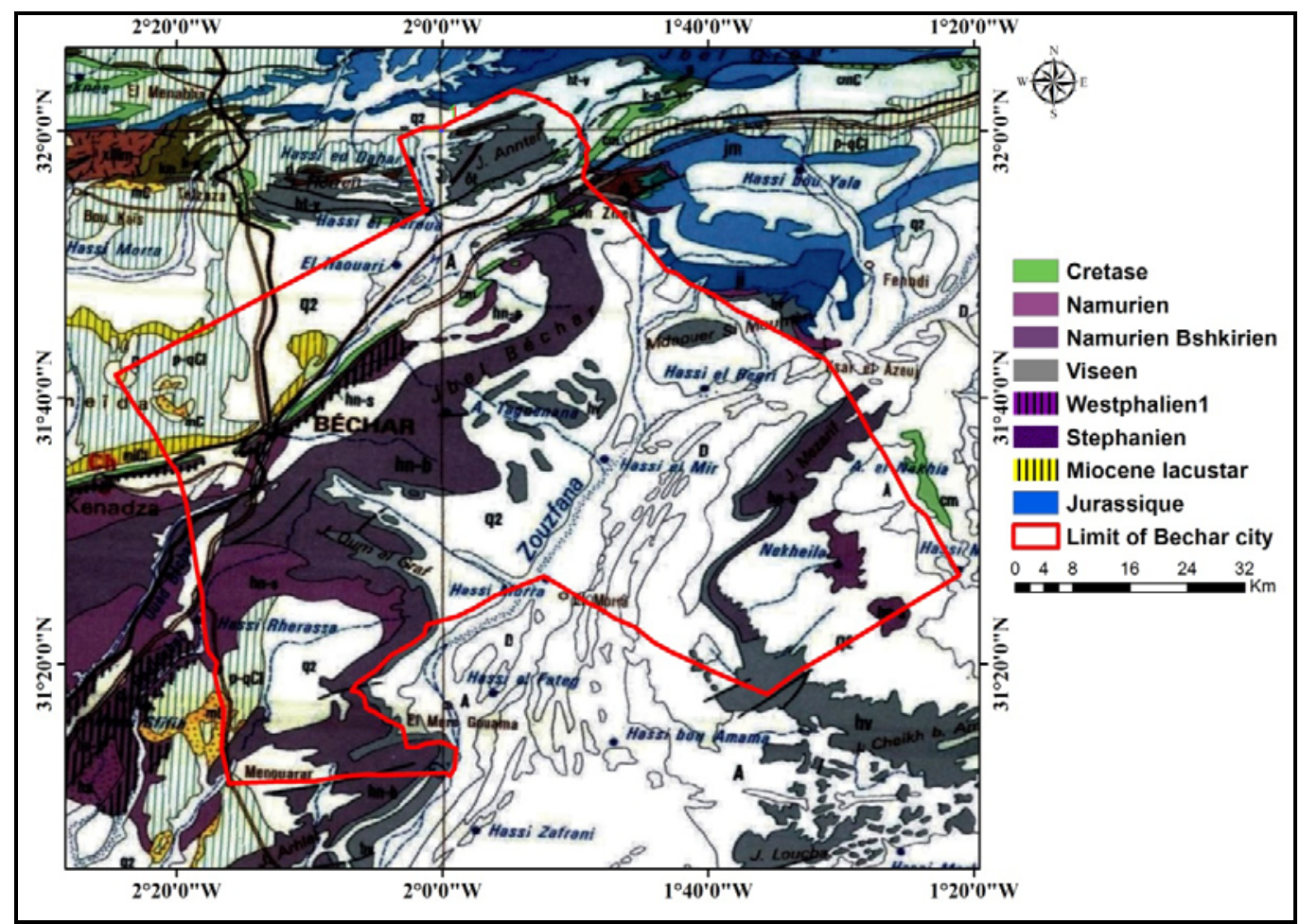

Fig. 2. Geological map of the city of Bechar; source: own elaboration source: own elaboration

The small town of Beni-Ounif is primarily founded on the recent Quaternary and Continental Albian. The bedrock of the town of Bechar, represented by Upper Westphalianage sites, generally consists of quartz sandstone beds, clays and coal-bedded schists (Fig. 2) [DELEAU 1952; MENCHIKOFF 1936; PAREYN 1961].

\section{MORPHOLOGICAL CONTEXT}

The Saharan Atlas consists of a long chain of very old mountains, stripped and sometimes quite high. As such, one can mention Djebel Antar (1953 m a.s.l.), Djebel

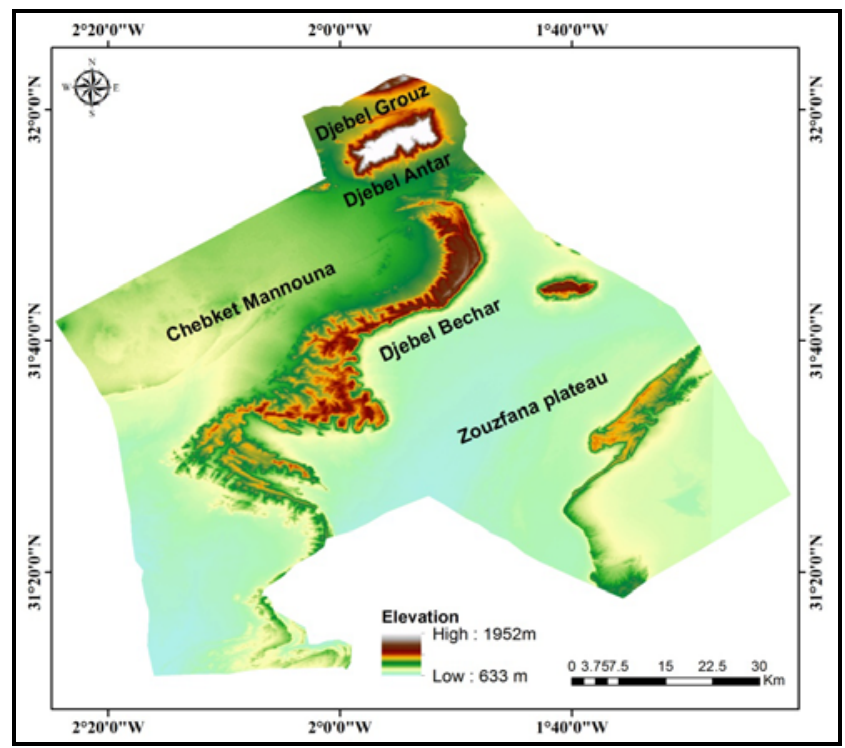

Fig. 3. Morphological map of the city of Bechar; source: own elaboration
Grouz (1835 m a.s.1.) and Djebel Bechar (1206 m a.s.1.), whose characteristics are fundamentally similar throughout the massif, i.e. from Morocco to the Aures Mountains (Fig. 3) [BENARADJ et al. 2012]. The elements of the relief are represented by a set of folded structural forms, more or less parallel to each other.

Altitudes above $2000 \mathrm{~m}$ inside the chain decrease southward rapidly [BENARADJ et al. 2012].

\section{CLIMATIC AND HYDROLOGICAL CONDITIONS}

The climatic aspects were studied in order to show the impact of the climate on the study area and to determine the different climatic factors that have to do with the subject of research, which in this case is flooding.

To do this, it was decided to pay particular attention to the climate of the watershed of Wadi Bechar and more specifically to precipitation, which is the most important factor directly affecting the floods.

The climatic conditions of the watershed play a vital role in the hydrological behaviour of the watercourses. It is important to remember that precipitation, especially liquid precipitation, is an essential parameter for flooding.

\section{PRECIPITATION}

Precipitation in the region of Bechar decreases from the North, with values greater than $100 \mathrm{~mm}$, to the South with values less than $50 \mathrm{~mm}$.

Table 2 summarizes the monthly and annual averages of precipitation recorded at the station of Bechar during two different periods:

- the first period is between 1968 and 1973,

- the second period is between 1981 and 2010. 
Table 2. Monthly and annual average precipitation, for the period extending from 1968 to 2010

\begin{tabular}{|l|c|c|}
\hline \multirow{2}{*}{ Month } & \multicolumn{2}{|c|}{ Precipitation $(\mathrm{mm})$ for } \\
\cline { 2 - 3 } & $1968-1973$ & $1981-2010$ \\
\hline September & 7.90 & 6.87 \\
\hline October & 12.00 & 13.10 \\
\hline November & 10.42 & 9.89 \\
\hline December & 11.19 & 8.64 \\
\hline January & 9.41 & 6.37 \\
\hline February & 6.99 & 5.18 \\
\hline March & 9.74 & 7.66 \\
\hline April & 9.83 & 9.93 \\
\hline May & 4.09 & 3.05 \\
\hline June & 1.68 & 2.50 \\
\hline July & 0.95 & 0.12 \\
\hline August & 3.24 & 2.75 \\
\hline Annual average & 86.73 & 84.46 \\
\hline
\end{tabular}

Source: ONM [2011]

\section{TEMPERATURE}

Average annual temperatures are around $21^{\circ} \mathrm{C}$ (Tab. 3). The highest monthly value $\left(34.4^{\circ} \mathrm{C}\right)$ was registered in July and the lowest value $\left(9.36^{\circ} \mathrm{C}\right)$ in the month of December (Tab. 3).

Table 3. Monthly and annual average temperature for the period between 1968 and 2010

\begin{tabular}{|l|c|c|c|c|}
\hline \multirow{2}{*}{ Month } & \multicolumn{4}{|c|}{ Temperature $\left({ }^{\circ} \mathrm{C}\right)$ in period } \\
\cline { 2 - 5 } & $1968-1973$ & $1975-1984$ & $1985-1999$ & $2000-2010$ \\
\hline September & 10.2 & 9.8 & 10.1 & 9.3 \\
\hline October & 12.3 & 12.9 & 13.0 & 12.1 \\
\hline November & 15.3 & 16.3 & 16.0 & 16.5 \\
\hline December & 19.0 & 19.9 & 19.7 & 20.5 \\
\hline January & 23.8 & 23.6 & 23.5 & 25.5 \\
\hline February & 28.6 & 30.1 & 29.8 & 30.4 \\
\hline March & 33.0 & 32.0 & 33.0 & 34.0 \\
\hline April & 32.0 & 32.9 & 32.6 & 33.4 \\
\hline May & 27.5 & 28.0 & 27.9 & 28.3 \\
\hline June & 21.0 & 21.3 & 21.4 & 22.1 \\
\hline July & 15.2 & 14.7 & 14.9 & 15.1 \\
\hline August & 9.4 & 10.0 & 11.0 & 11.0 \\
\hline Annual average & 20.58 & 21.2 & 21.1 & 21.5 \\
\hline
\end{tabular}

Source: ONM [2011].

Table 4. Annual variations in flow rates at the station of Bechar from 1985 to 2010

\begin{tabular}{|c|c|c|c|}
\hline Year & Flow rate $\left(\mathrm{m}^{3} \cdot \mathrm{s}^{-1}\right)$ & Year & Flow rate $\left(\mathrm{m}^{3} \cdot \mathrm{s}^{-1}\right)$ \\
\hline 1985 & 40 & 1998 & 1.89 \\
\hline 1986 & 95 & 1999 & 25 \\
\hline 1987 & 13.4 & 2000 & 17 \\
\hline 1988 & 22.5 & 2001 & 1.15 \\
\hline 1989 & 19.4 & 2002 & 2.05 \\
\hline 1990 & 20.8 & 2003 & 20.5 \\
\hline 1991 & 32 & 2004 & 22 \\
\hline 1992 & 10 & 2005 & 0 \\
\hline 1993 & 11 & 2006 & 40 \\
\hline 1994 & 60 & 2007 & 20 \\
\hline 1995 & 11 & 2008 & 850 \\
\hline 1996 & 30 & 2009 & 30 \\
\hline 1997 & 15.2 & 2010 & 2 \\
\hline
\end{tabular}

Source: ANRH [2011].

\section{FLOW RATES}

In this study, the annual flow values of the hydrometric station of the National Agency for Hydraulic Resources (ANRH) were taken into consideration.

The interannual distribution of flow rates shown in Table 4 shows a significant decrease during the period between 1997 and 2007. However, a surge in flow was noted during the year 2008, this being due to the precipitation of the month of October 2008, which caused the exceptional floods of 2008.

\section{STATISTICAL APPROACH}

\section{Adjusting runoff}

Our study is based on the techniques of the adjustment or calibration of a frequency model to a series of data, it is to define the parameters of the chosen law. We used Gumbel law, frequently used in hydrology, to model the extreme events of the rains [EPFL 2004].

For the Wadi Bechar watershed (Bechar station), located upstream of the Wadi Bechar stream, we proceeded to:

- frequency analysis of annual maximum flows observed according to a Gumbel distribution;

- adjust the data by the method of moments;

- estimate peak flow rates of return time $T=5,20,50$, 100 years.

The results obtained through the production of this adjustment are shown in Table 5, which is a series of annual maximum flows in $\mathrm{m}^{3} \cdot \mathrm{s}^{-1}$ [EPFL 2004].

Table 5. Statistical results of flow rate adjustments obtained by Gumbel law and the method of moments, between 1985 and 2010

\begin{tabular}{|c|c|c|c|}
\hline $\begin{array}{c}\text { Return period } T \\
\text { (years) }\end{array}$ & $\begin{array}{c}\text { Probability of not } \\
\text { exceeding }\end{array}$ & $\begin{array}{c}\text { Reduced variable } \\
\text { of Gumbel }\end{array}$ & $Q p\left(\mathrm{~m}^{3} \cdot \mathrm{s}^{-1}\right)$ \\
\hline 100 & 0.99 & 4.6 & 567.3 \\
\hline 50 & 0.98 & 3.9 & 478.3 \\
\hline 25 & 0.96 & 3.2 & 388.6 \\
\hline 5 & 0.80 & 1.5 & 172.0 \\
\hline 2 & 0.57 & 0.6 & 54.5 \\
\hline
\end{tabular}

Source: own study

The present study is based on the techniques of adjustment or calibration of a frequency model to a series of data. In this case, the parameters of the selected law must be clearly defined. Gumbel's law was used as a pedagogical support. This law is frequently used in hydrology for the modelling of extreme rainfall events [EPFL 2004].

For the watershed of Wadi Bechar (Bechar Station), located upstream of the watercourse of Wadi Bechar, the following steps were followed:

- frequency analysis of annual maximum flows observed, according to Gumbel's distribution;

- adjustment of data by the method of moments;

- estimation of peak flows for different return times, i.e. $T=5,20,50,100$ years.

The results obtained through the implementation of this adjustment are summarized in Table 5. This is a series of annual maximum flow rates in $\mathrm{m}^{3} \cdot \mathrm{s}^{-1}$ [EPFL 2004]. 
It can be seen that Gumbel law fits well with the peak flow rate values (Fig. 4). The analysis of annual maximum flow rates observed according to the Gumbel law distribution with the use of the method of moments makes it possible to estimate the flow rates for the different return periods, i.e. $T=2,5,25,50$ and 100 years.

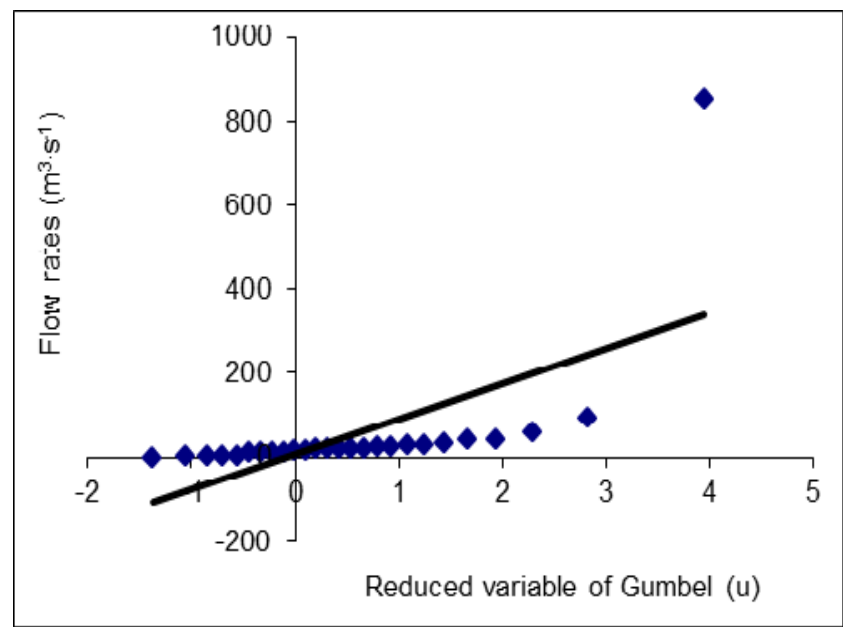

Fig. 4. Gumbel diagram; source: own elaboration

As the hydrometric data are available for the 25-year period, the fitting of the maximum flow series to Gumbel law, which is a distribution commonly used in flood survey, allowed obtaining the quantiles summarized in Table 5 .

\section{Hydraulic modelling software HEC-RAS and HEC-GeoRAS}

The HEC-RAS model. In order to master one of the computer tools to model the flow, it was decided to choose the one-dimensional model (1D) HEC-RAS which has a version available for free and easy to use. The data required for this hydraulic modeling are the flow rates resulting from the hydrological study, the geometry of the watercourse that crosses the city of Bechar as well as the longitudinal slope and the roughness of the bed and banks at the different calculation points.

This modelling is a simplified schematization of a real system of a free surface flow. The purpose is to have the runoff corresponding to the different flow rates from the hydrological study for use in the next section that aims to map the Alea.

The Hydrologic Engineering Center River Analysis System (HEC-RAS) is a one-dimensional model designed by the US Army Corps of Engineers of the Hydrologic Engineering Center to model the permanent and nonpermanent free surface flows. This software was designed to perform the following tasks:

- calculate the heights of water in a steady state;

- simulate the non-permanent flow;

- calculate the solid transport capacity;

- analyse the quality of water.

The three dimensions may be found in the same geometry. In addition, the system has several hydraulic characteristics that can be used once the water lines have been calculated.
The model is in continuous development. The current version is HEC-RAS 4.0, which is characterized, in comparison with previous versions, by its improved capacity of calculating the solid transport and other features related to water quality [USACE 2010].

The HEC-GeoRAS model. The HEC-GeoRAS software includes a set of procedures, tools, and utilities for processing geospatial data in ArcGIS using a graphical user interface (GUI). The interface allows preparing the geometric data to be imported into HEC-RAS in order to process the simulation results obtained with HEC-RAS. For the purpose of creating the import file, the user must have a digital terrain model (DTM) existing in the river system, in the TIN ArcInfo format. The user creates a series of relevant line themes in order to develop geometric data for the HEC-RAS software. The themes created are the stream center line, the stream path center lines (optional), the main channel banks (optional), and the crosssectional cut lines, also called RAS themes.

Additional RAS themes can be created and used to extract additional geometric data to be imported into HECRAS. These themes include the land use, levee alignment, ineffective drainage areas and storage areas.

The water surface profile data and the speed data exported from the HEC-RAS simulations can be processed by the HEC-GeoRAS software for GIS analysis for the purpose of mapping the floodplains, assessing the damage caused by floods, restoring the ecosystem and preparing for floods [USACE 2002].

\section{RESULTS AND DISCUSSION}

\section{ELABORATION OF THE MAPS OF WADI BECHAR}

\section{Tracing Wadi Bechar}

The quality of hydraulic modelling is highly dependent on the quality of the topographic data. These data depend significantly on two main factors, namely the precision and the resolution. Several acquisition techniques, more or less sophisticated, can be used depending on the objective envisaged by the study and the budget allocated [CHACHOUA 2009].

The resolution presents the mesh fineness of surveys in the field as well as the precision and absolute error on the measurements. The quality differs between the minor bed and the major bed. Indeed, there are two types of surveys, namely the seeding point survey and the cross-sectional survey. When a one-dimensional model is used, the geometry is described by a set of cross-sections that must be chosen wisely in order to cover all features of the longitudinal profile, namely the contractions and expansions of the flow as well as the important details of geometry.

For a large-scale hydraulic study, it is necessary to provide very extensive topographic data of fine resolution and high precision.

Therefore, it is highly recommended to choose the survey method that offers the best relationship between the quality required by the study on the one hand and the acquisition cost, on the other. 


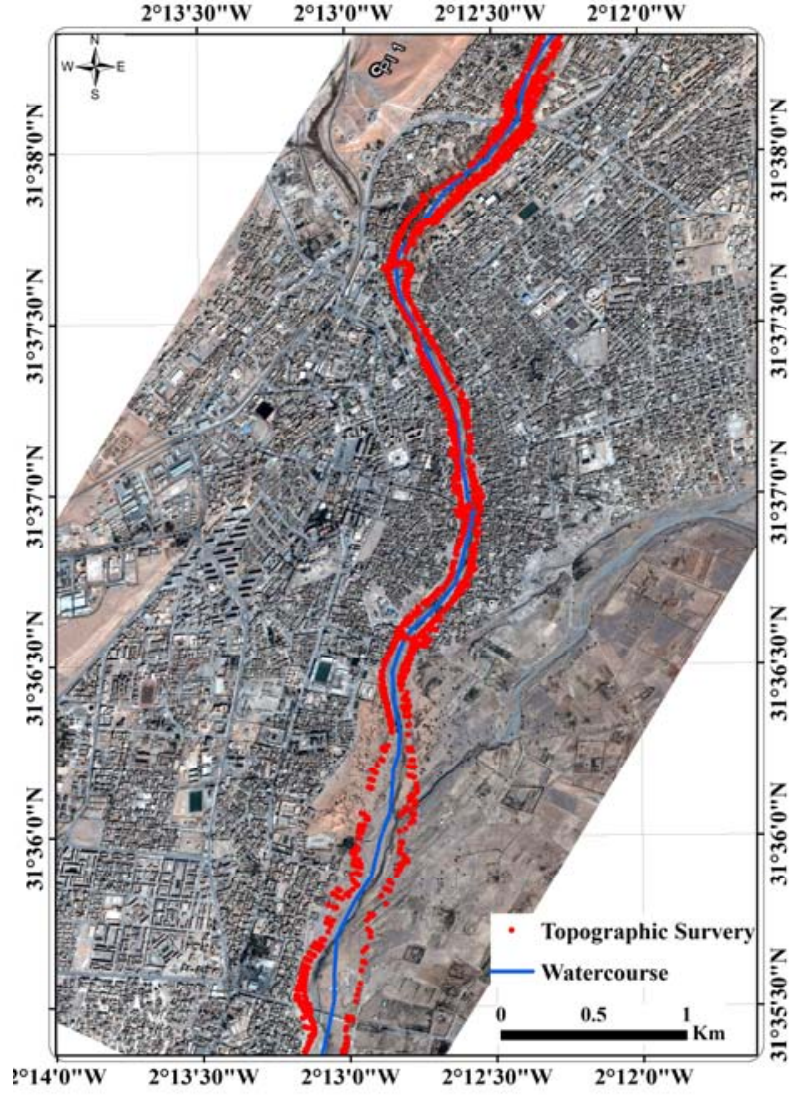

Fig. 5. Wadi Bechar topographic survey extension map; source: own study

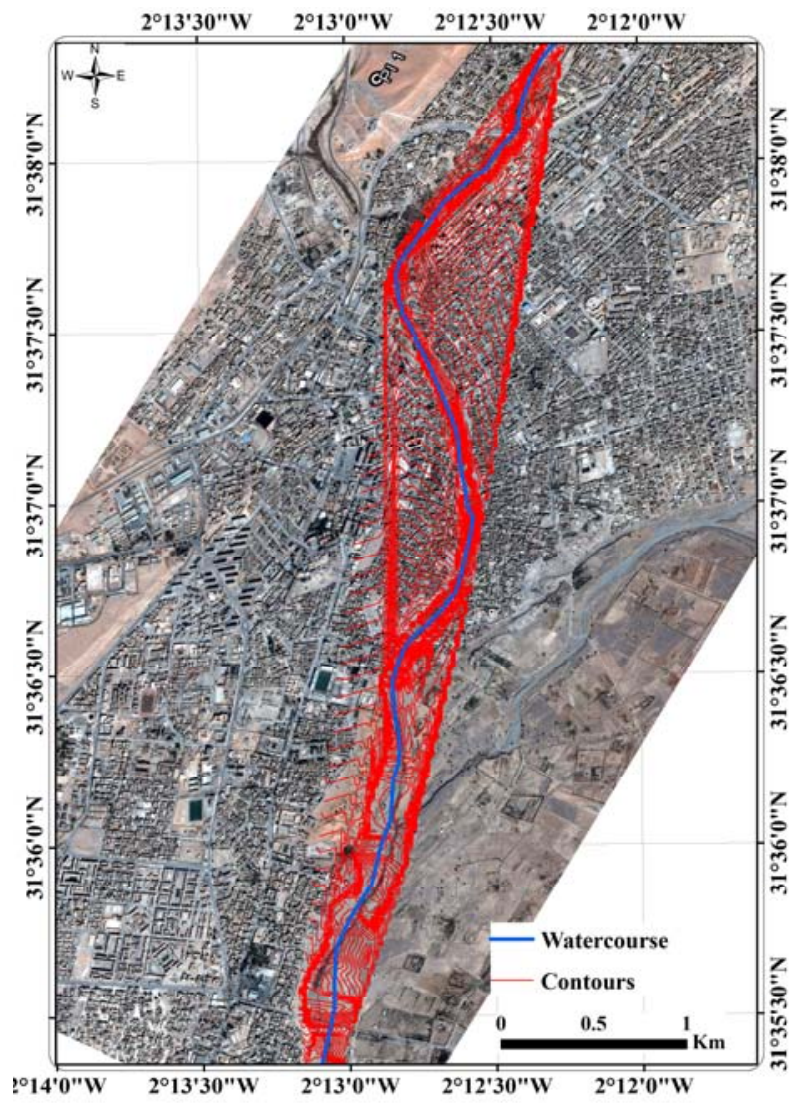

Fig. 6. Contour map of Wadi Bechar; source: own study

\section{Topography of Wadi Bechar}

The topographic survey (Fig. 5) was carried out over a length of $17000 \mathrm{~m}$ and a width of $300 \mathrm{~m}$ by surveyors from a design office as part of a hydraulic study of Wadi Bechar [BEKHIRA et al. 2014]. This topographic survey is used to draw contours using ArcGis (Fig. 6).

Since Wadi Bechar is very long, it was decided to draw two separate maps of the studied surface.

\section{THE DIGITAL MODEL OF WADI BECHAR WATERCOURSE}

The high resolution Digital Terrain Model (DEM) was created based on the Wadi Bechar topographic survey using the ArcGis software (Fig. 7).

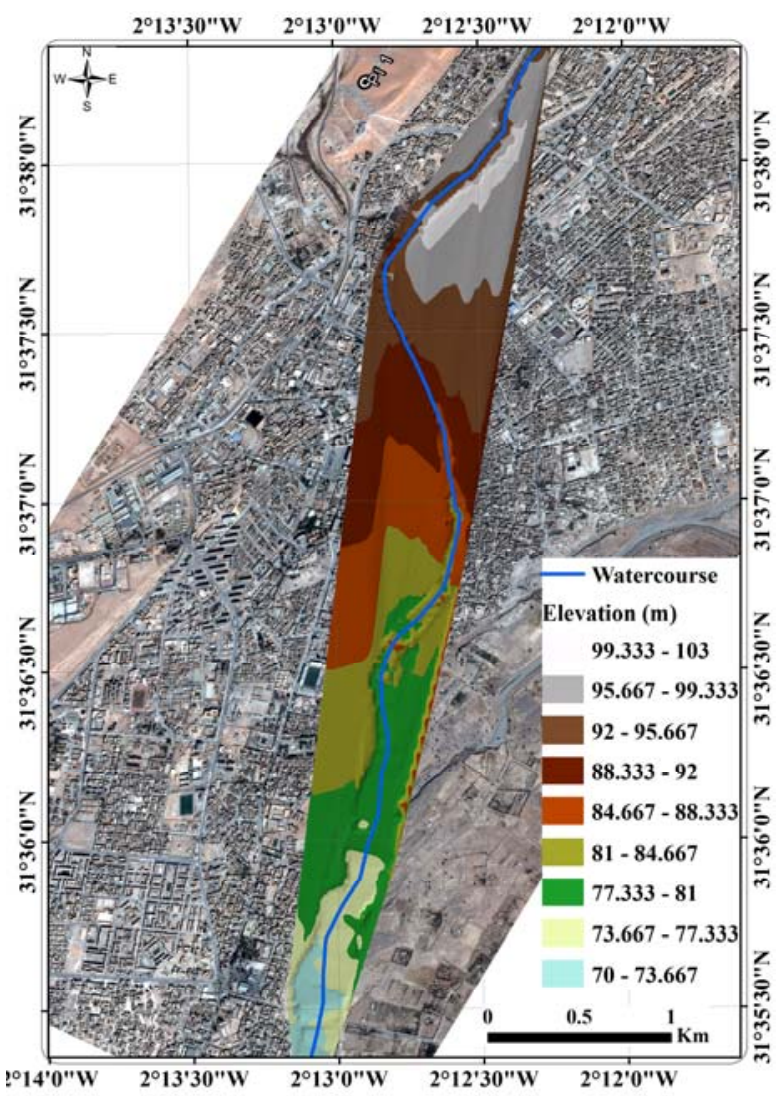

Fig. 7. Three-dimensional (3D) representation of Wadi Bechar, according to the digital elevation model (DEM); source: own study

\section{LONGITUDINAL PROFILE AND CROSS-SECTIONAL PROFILES OF THE WATERCOURSE OF WADI BECHAR}

It is important to use the same digital elevation model (DEM) employed in the extraction of the cross sections (Figs. 8, 10) in order to get a modelling that is consistent with the mapping report [FARISSIER 1993].

HEC-GeoRAS, the free GIS extension in ArcGis, allows the software Arcview to read HEC-RAS export files [KREIS 2004].

This HEC-GeoRAS program, specifically designed to process the geospatial data, is an interface between HECRAS and ArcGIS. 


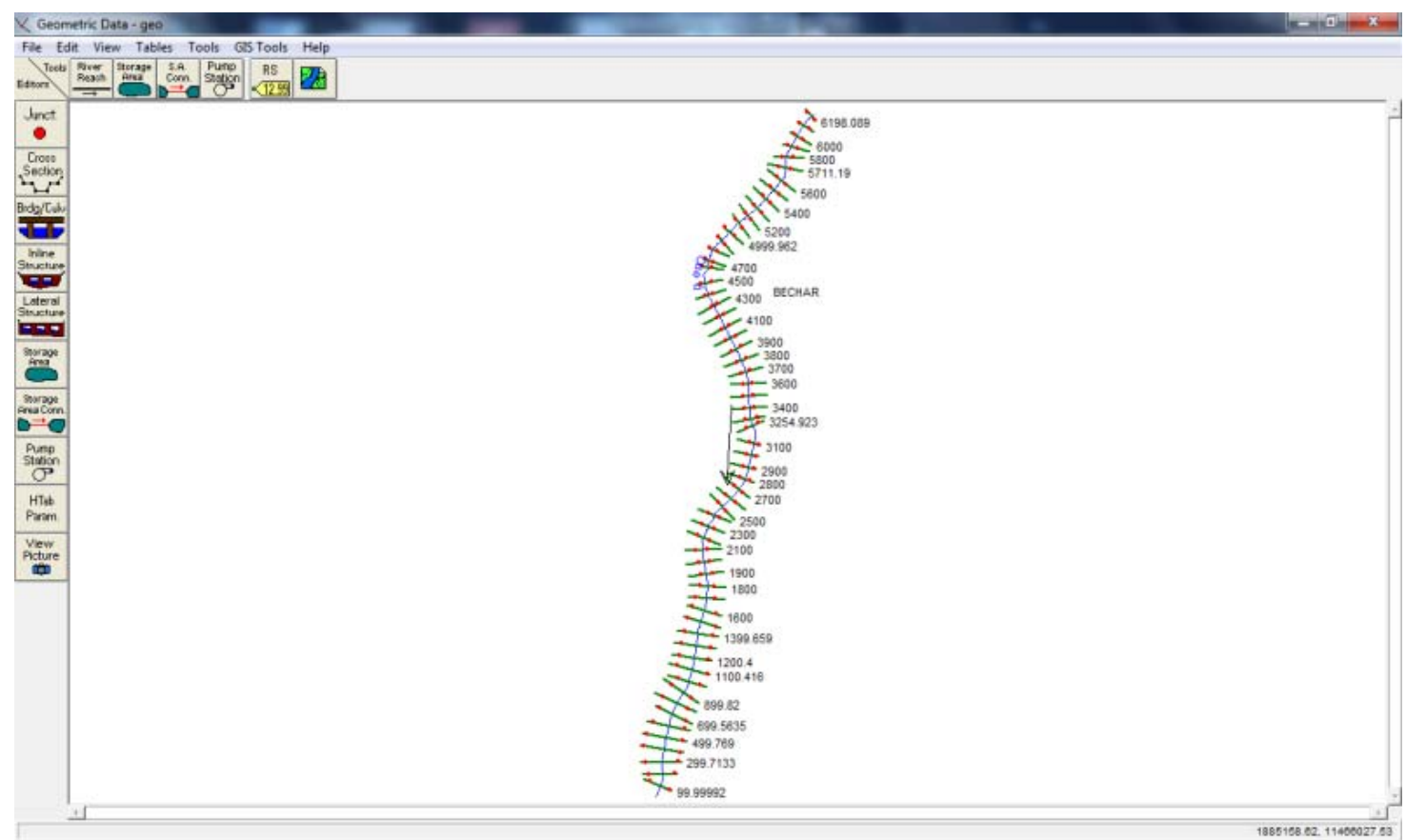

Fig. 8. Wadi Bechar geometries calibrated into the model HEC-RAS; source: own study

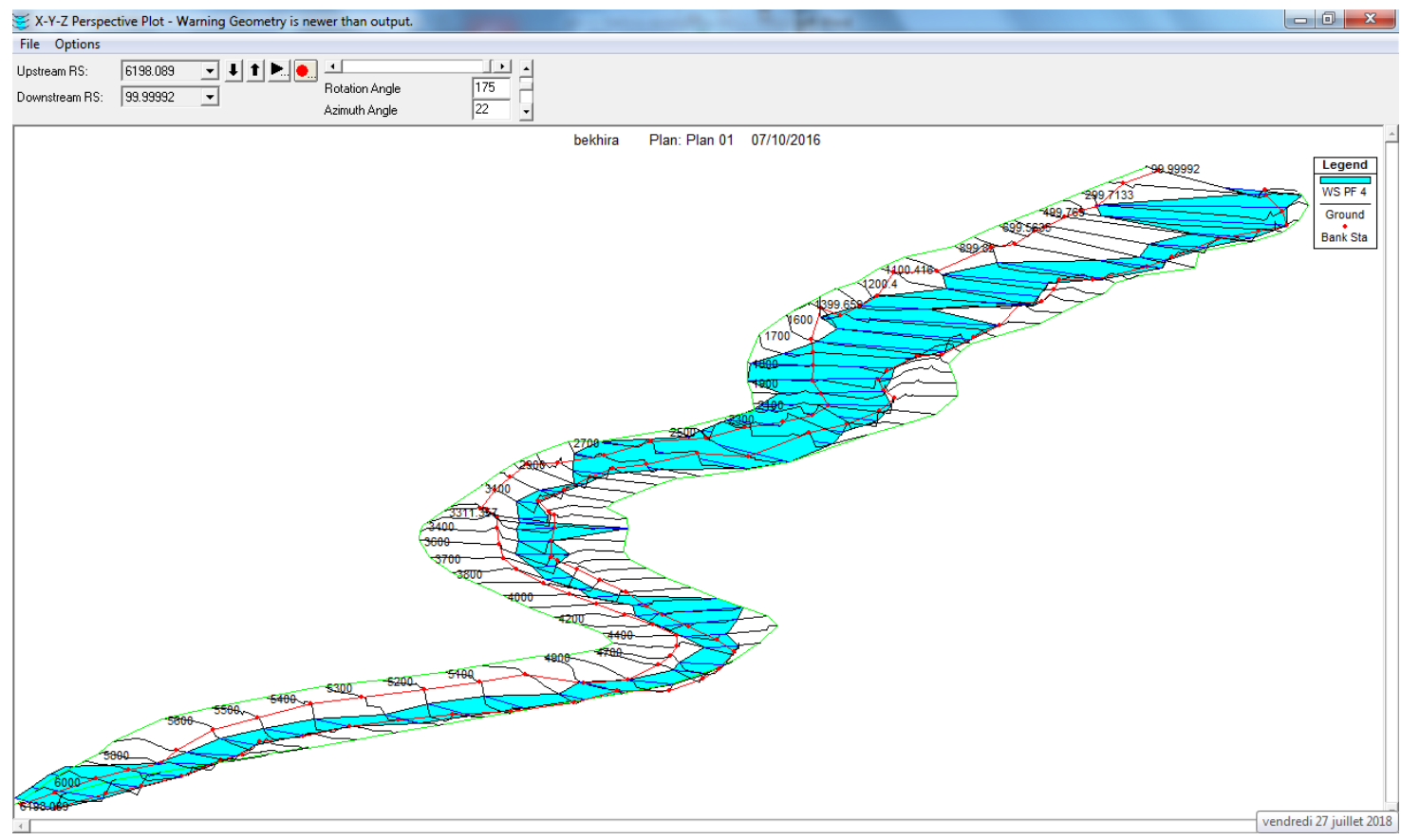

Fig. 9. XYZ perspective plot of Wadi Bechar; source: own study

Regarding the way the model performs the calibration between different points, it was decided to compare the observations made in situ with the results obtained by the HEC-RAS model in the steady state. This led to the conclusion that the calibration points on the boundary are superimposed and well calibrated (Fig. 10).

\section{NUMERICAL SIMULATION OF WADI BECHAR FLOOD}

The Geographic Information System (GIS) allows creating a digital surface model (DSM) of water during the flooding from the maximum water line [KREIS 2004]. It is possible to imagine the hydraulic simulation in a gradually varied regime with three reference events resulting from the previous hydrological modelling (Fig. 9). These events correspond to the return periods of 25 years $\left(Q_{25}=388.6\right.$ $\left.\mathrm{m}^{3} \cdot \mathrm{s}^{-1}, h_{\text {water }}=3.5 \mathrm{~m}, b=200 \mathrm{~m}, S_{\text {spot }}=55.35 \mathrm{ha}\right), 50$ years $\left(Q_{50}=478.3 \mathrm{~m}^{3} \cdot \mathrm{s}^{-1}, h_{\text {water }}=5 \mathrm{~m}, b=200 \mathrm{~m}, S_{\text {spot }}=66.48\right.$ ha) and 100 years $\left(Q_{100}=567.3 \mathrm{~m}^{3} \cdot \mathrm{s}^{-1}, h_{\text {water }}=7 \mathrm{~m}, b=\right.$ $200 \mathrm{~m}, S_{\text {spot }}=133 \mathrm{ha}$ ), in the same climate regime; HAFNAOUI et al. [2013] found that the 10-year, 100-year, and 1000 -year flood rates were approximately equal to 167.3 , 367.4 , and $603.2 \mathrm{~m}^{3} \cdot \mathrm{s}^{-1}$, respectively. 


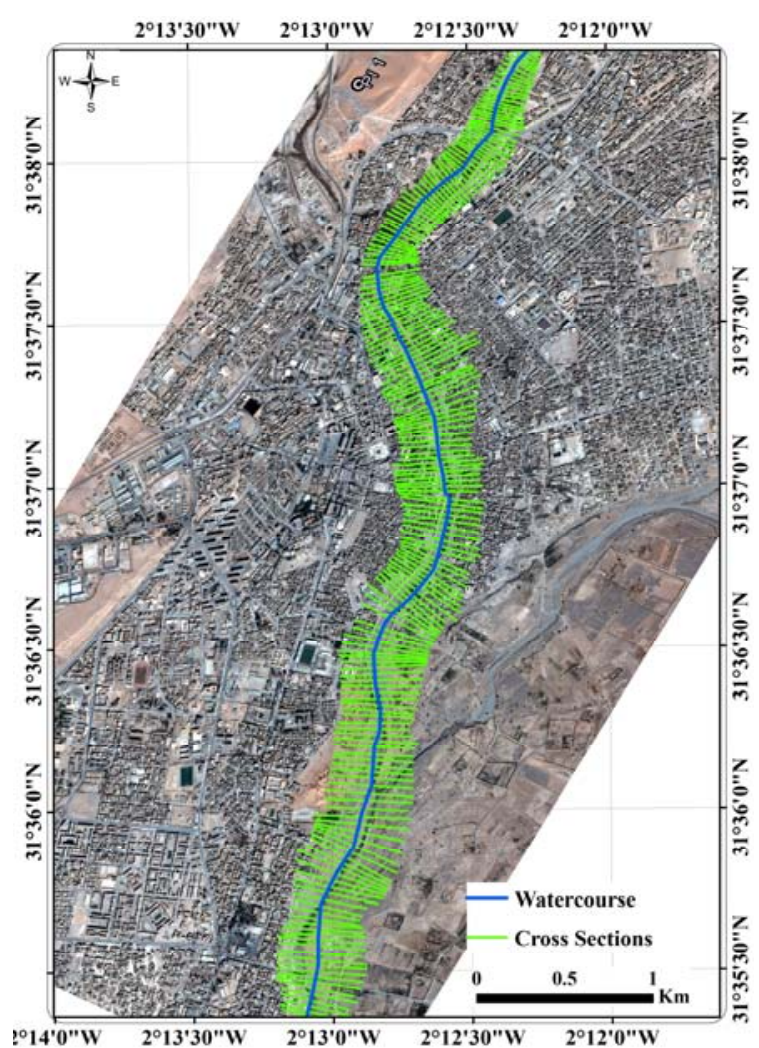

Fig. 10. Plot of cross-sectional profiles and longitudinal profile with respect to streamlines, with maximal extension of the cross-sectional profiles; source: own study

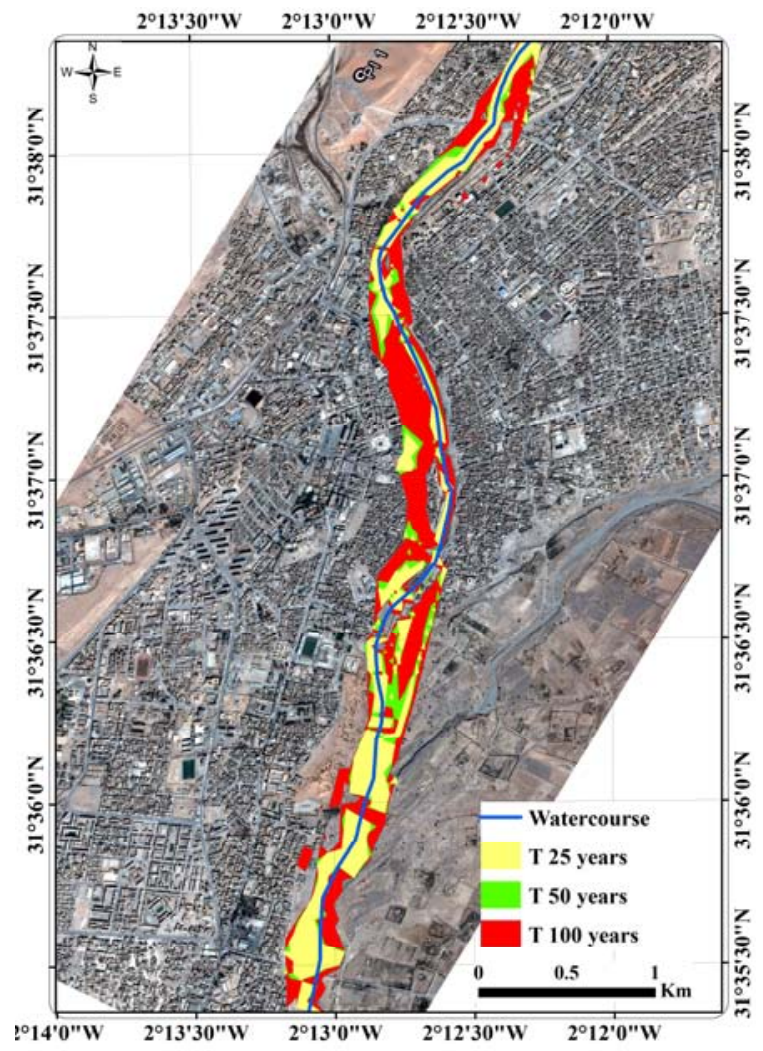

Fig. 11. Results of the numerical simulation of floods of Wadi Bechar; source: own study
The roughness is considered as homogeneous on the bedrock, along the minor bed of Wadi Bechar; the value of $n=0.040$ corresponds to a bed with meanders, with some ponds and clean shallow places. On the other hand, this roughness is variable on the left and right banks of the river; it ranges from 0.035 to 0.055 , depending to the nature of soil along Wadi Bechar; it is equal to 0.012 on the walls of the bridge. The results obtained from the digital flood simulation of Wadi Bechar for the flow rates of the different time steps are shown in Figure 11.

\section{FLOOD MAPPING}

The map shown in Figure 12 presents the heights of the flood in the town of Bechar in the case of a centennial flood of Wadi Bechar. It is easy to notice that the maximum height is $7.66 \mathrm{~m}$ and the flood spot surface is equal to $133 \mathrm{ha}$, in the same climate and in another watershed YAMANI et al. [2016] find de maximum height is equal to $5 \mathrm{~m}$, and 0.036875 ha of flood spot surface.

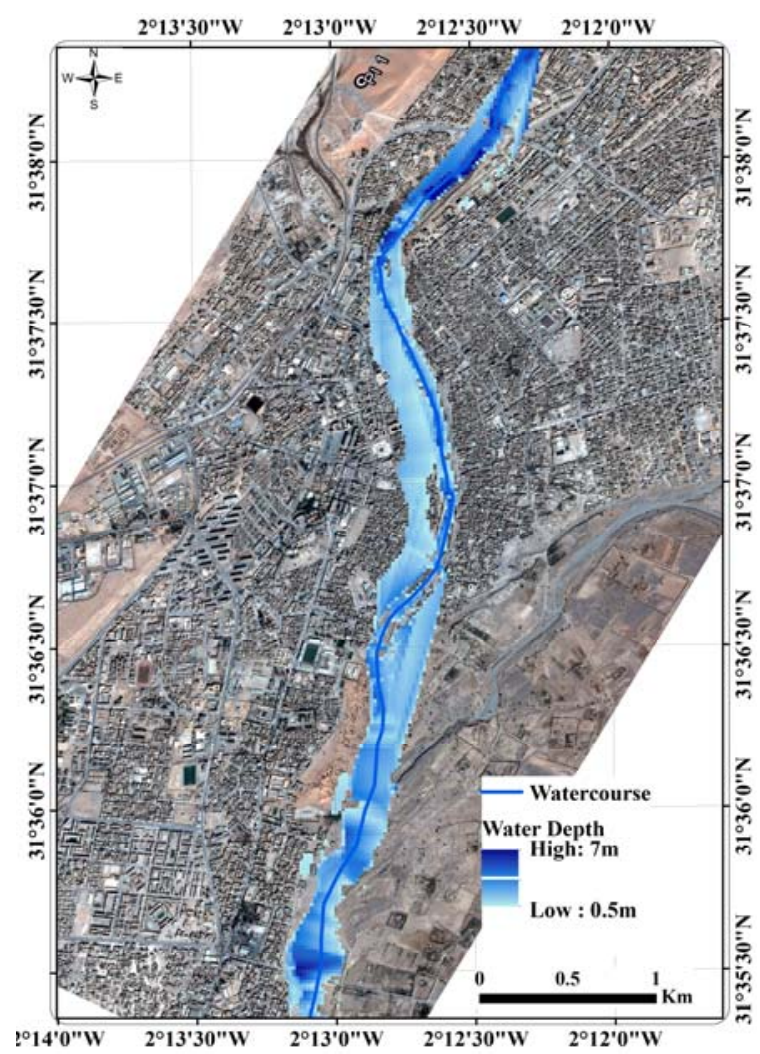

Fig. 12. Map of the flood height of Wadi Bechar; source: own study

- The very high flood risk areas are shown in Figure 12 in dark blue colour. In these areas, such as Ba Zayde Bridge, Hai El Nour, El Mzarif and El Guettara which are located in the immediate vicinity of the Wadi bed, the level of water can reach the height of 6.00 to $7.66 \mathrm{~m}$. These areas have suffered a lot from flooding as a large number of houses were built in the bed of the Wadi (Fig. 1). 
- The high risk areas are in dark blue, of which $40 \%$ is in lighter colour, as shown in Figure 12. These regions are closer to the wadi bed. They are dangerous during floods as the water level can reach 5 or $6 \mathrm{~m}$. They mainly occupy the congested areas near the bridges, such as the El Safsaf district, next to the Ba Zaide bridge, Debdaba in the center, the old Ksar and Hai Nour.

- The moderate risk areas are in dark blue colour, of which $60 \%$ is in lighter colour, as displayed in Figure 12 , where the height of water may vary between 2 and $3 \mathrm{~m}$. These areas can become at high risk in the event of heavy rains, especially near the bed and along the wadi; this is certainly due to the narrowing of the wadi bed, or to the artificial banks or houses.

- The low risk areas are represented by the light blue colour in Figure 12; the height of water does not exceed $1 \mathrm{~m}$. These areas, such as the districts of Mkhalif, Salam, Gharassa and Bechar Djedid, are generally far from the bed of the wadi and its tributaries. These areas are little exposed to the risk of flooding.

The diagnosis and analysis of priority sites allowed identifying the following main causes of floods:

- the morphology of the watershed of Wadi Bechar which is characterized by steep slopes $\left(S_{\text {mean }}=0.00321 \mathrm{~m} \cdot \mathrm{m}^{-1}\right)$ [BOULANOUAR 2007], degradation of the grounds and limited permeability favouring the genesis of floods and the amplification of their peak flows;

- the narrowing of watercourse sections due to deposits of solids and discharges of all kinds $\left(0.53 \mathrm{~kg} \mathrm{~m}^{-2} \cdot \mathrm{year}^{-1}\right)$ [BOULANOUAR 2007] which impede the flow of water and therefore oppose the flood evacuation in normal and natural hydraulic conditions;

- the anarchic occupation of the public domain by illegal constructions and the concentration of economic activities near the wadi beds, for example in the district of Debdaba where the population density is 100 inhabitants per hectare and Bechar centre with a density of 76 inhabitants per hectare [HALILOU 2011];

- the inappropriate design of certain bridges and crossing structures of wadis (sewerage networks) in which the branches brought by the floods constitute an obstacle to the normal flow of water;

- the inappropriate sizing of watercourse structures across urban centres and agglomerations.

\section{CONCLUSIONS AND RECOMMENDATIONS}

The city of Bechar is characterized by an arid desert climate where rainfall is rare and also potential evaporation is quite frequent during the summer season, which engenders a great drought. Wadi Bechar has rarely experienced strong floods. Those that occasionally occur are quite mild and are generally spaced out by long periods. This situation has encouraged the construction of houses on the banks of the wadi.

The results obtained for 25, 50 and 100 years are presented as follows $\left(Q_{25}=388.6 \mathrm{~m}^{3} \cdot \mathrm{s}^{-1}, h_{\text {water }}=3.5 \mathrm{~m}, b=\right.$ $\left.200 \mathrm{~m}, S_{\text {spot }}=55.35 \mathrm{ha}\right), 50$ years $\left(Q_{50}=478.3 \mathrm{~m}^{3} \cdot \mathrm{s}^{-1}, h_{\text {water }}\right.$ $\left.=5 \mathrm{~m}, b=200 \mathrm{~m}, S_{\mathrm{spot}}=66.48 \mathrm{ha}\right)$ and 100 years $\left(Q_{100}=\right.$ $\left.567.3 \mathrm{~m}^{3} \cdot \mathrm{s}^{-1}, h_{\text {water }}=7 \mathrm{~m}, b=200 \mathrm{~m}, S_{\text {spot }}=133 \mathrm{ha}\right) \mathrm{re}-$ spectively,

This work allowed showing that floods have also become a critical risk for the town of Bechar. They need to be seriously taken into account while planning local development programs in order to identify the areas at risk of flooding; this will help to classify these areas according to the height of flood waters in order to minimize damage from natural disasters and floods for the purpose of reducing the impact of flooding on the study area and to protect the city of Bechar and the agglomerations exposed to this risk.

This work also allowed providing appropriate decision support elements that can help develop an adequate layout plan for the City of Bechar. Improvements are highly recommended for better flood risk management at Wadi Bechar watercourse and also for the development of an efficient flood prevention scheme.

\section{REFERENCES}

ANRH 2011. Rapport globale sur la région Sud Ouest [Global report on the South West region [National Agency for Hydraulic Resources]]. [02.03.2011 Bechar].

Atallah M., Hazzab A., Seddini A., Ghenaim A., Korichi K. 2018. Inundation maps for extreme flood events: Case study of Sidi Bel Abbes city, Algeria. Journal of Water and Land Development. No. 37 p. 19-27. DOI 10.2478/jwld-20180021.

BASAHI J., MASOUD M., ZAIDI S. 2016. Integration between morphometric parameters, hydrologic model, and geo-informatics techniques for estimating WADI runoff (case study Wadi Halyah - Saudi Arabia). Arabian Journal of Geosciences. Vol. 9:610 pp. 18.

Bekhira A., Habi M., Morsli B. 2018. Hydrological modeling of floods in the Wadi Bechar watershed and evaluation of the climate impact in arid zones (southwest of Algeria). Applied Water Science. Vol. 8. Iss. 6 p. 1-8.

Bekhira A., Nebou M., Merzougi T. 2014. Gestion des crues dans le bassin versant de l'Oued Béchar: etude hydrologique et amenagement [Flood management in the Wadi Bechar watershed: hydrological study and development]. MSc Thesis. Bechar. Tahri Mohammed University pp. 159.

Benaradj A., Boucherit H., Bouazza M., Baghdadi D., Aibout F. 2012. Particularité géologique de l'atlas saharien oranais (Béchar). En: $2^{\text {ème }}$ Colloque International sur La Géologie du Sahara-Ressources minérales, enhydrocarbures et en eau [Geological particularity of the Oran Saharan atlas (Bechar). In: $2^{\text {nd }}$ International Symposium on Geology of the Sahara-Mineral Resources, Hydrocarbons and Water]. 3-5.12.2012 Ouargla p. 19-29.

Boulanouar S. 2007. Caractérisation hydrologique du bassin versant d'Oued Saoura (Sud Ouest Algérien) [Hydrological characterization of the watershed of Oued Saoura (South West Algeria)]. MSc Thesis. Bechar. Tahri Mohammed University pp. 23.

Bouzahar F., Ouerdachi L., Keblouti M., Seddiki A. 2018. The contribution of remote sensing in hydraulics and hydrology, analysis and evaluation of digital terrain model for flood risk mapping. Journal of Water and Land Development. No. 39 p. 17-26. DOI 10.2478/jwld-2018-0055.

Chachoua A. 2009. Gestion de crue dans un bassin versant: Etude hydrologique, hydraulique et aménagement [Flood management in a watershed: Hydrological, hydraulic and 
development study]. MSc Thesis. Tlemcen. University of Tlemcen pp. 135.

Deleau P. 1952. La région de Colomb-Béchar - Monographie régionale [The region of Colomb-Bechar - Regional monograph]. XIXe Congrès de Géologie International. Algeria. Vol. 1. No. 8 pp. 101.

Derdous O., DJemili L., Bouchehed H., TAChi S.E. 2015. A GIS based approach for the prediction of the dam break flood hazard - A case study of Zardezas reservoir "Skikda, Algeria". Journal of Water and Land Development. No. 27 p. 1520. DOI 10.1515/jwld-2015-0020.

EPFL 2004. Estimations du débit de pointe de temps de retour 20 et 100 ans par la méthode statistique et celle du GRADEXApplication au bassin versant de la Viège à Viège (VS, Suisse) [20 and 100 year peak flow rate estimates by statistical method and GRADEX - Application to the Visp watershed at Visp (VS, Switzerland)] [online]. Lausanne. [Access 08.04.2004]. Available at: http://www.lthe.fr/PagePerso/ hingray/PAGES/Hydrotheque/Hydrologie_Appliquee/08_ EtudedesCrues/Exercice_HA0802/HA0802_enonce.pdf ${ }^{-}$

FARISSIER P. 1993. Etude d'un modèle de cartographie adapté à la simulation des écoulements en rivière [Study of a mapping model adapted to the simulation of river flows]. CEMAGREF. PhD Thesis. Lyon. University of Lyon I p. 211.

Hafnaoui M.A., Hachemi A., Ben Said M., Noui A., FeKraoui F., MAdi M., Mghezzi A., DJABri L. 2013. Vulnérabilité aux inondations dans les régions sahariennes - cas de Doucen [Vulnerability to floods in the Saharan regions - Case of Doucen]. Journal Algérien des Régions Arides. No. 12 p. $148-155$.

Haghizadeh A., Teang S.L., Mirzaei M., Memarian M. 2012. Incorporation of GIS based program into hydraulic model for water level modeling on river basin. Journal of Water Resource and Protection. Vol. 4. No.1 p. 25-31.

Halilou M.A. 2011. Historique et impact des inondations de l'Oued Béchar dans la ville de Béchar [History and impact of the floods of Oued Bechar in the city of Bechar]. MSc Thesis. Oran. University of Oran pp. 156.

Hoegh-Guldberg O., BRuno J.F. 2010. The impact of climate change on the world's marine ecosystems. Science. Vol. 328. Iss. 5985 p. $1523-1528$.

KREIS N. 2004. Modélisation des crues des rivières de moyenne montagne pour la gestion intégrée du risque d'inondation application a la vallée de la Thur (Haut-Rhin) [Modeling medium-mountain river floods for integrated flood risk management applied to the Thur valley (Haut-Rhin)]. PhD Thesis. Strasbourg. Louis Pasteur University pp. 350.

KuRIATA-PotAsZniK A.B., SZYMCZYK S. 2016. Variability of the water availability in a river lake system - A case study of Lake Symsar. Journal of Water and Land Development. No. 31 p. 87-96. DOI 10.1515/jwld-2016-0039.
MenChiKoff N. 1936. Etude géologique sur les confins AlgéroMaroccains du Sud [Geological study on the borders Algerian-Moroccan of the South]. Bulletin of the Geological Society of France. Ser. 5. T. 6 p. 131-148.

Merzougui T., Ghazli M., Rezzoug C. 2014. Risque des inondations dans le bassin versant de la Saoura (Bechar, Sud Ouest algérien) [Risk of flooding in the Saoura watershed (Bechar, Southwest Algeria)]. International Journal of Environment and Water. Vol. 3. Iss. 2 p. 23-95.

ONM 2011. Rapport globale sur la région de Béchar [Global report on the region of Bechar [National Metrological Office]]. [12.09.2011Bechar].

PAREYN C. 1961. Les massifs carbonifères du Sahara Sud-oranais [The Carboniferous Massive of the South Oran Sahara]. France. Centre de recherches sahariennes. Série géologie. 1. T. 1. No. 1. 2 vols. pp. 362.

Parhi P., SANKhUa R., Roy G. 2012. Calibration of channel Roughness for Mahanadi River (India) using HEC-RAS Model. Journal of Water Resource and Protection. Vol. 4. No. 10 p. $847-850$.

Patel C., Gundaliya P. 2016. Floodplain delineation using HECRAS model - A case study of Surat city. Open Journal of Modern Hydrology. Vol. 6. No. 1 p. 34-42.

Prafulkumar V.T., Prem L.P., Prakash D.P. 2011. Calibration of HEC-RAS model on prediction of flood for Lower Tapi River. Journal of Water Resource and Protection. Vol. 3. No. 11 p. $805-811$.

SchmidT A., IVANOva A., SchÄFER M.S. 2013. Media attention for climate change around the world: A comparative analysis of newspaper coverage in 27 countries. Global Environmental Change. Vol. 23. Iss. 5 p. 1233-1248.

USACE 2002. HEC-GeoRAS Extension for support of HECRAS using ArcView: User's. HEC-GeoRAS User Manual. Washington, DC. US Army Corps of Engineers. Hydrologic Engineering Center pp. 154.

USACE 2010. HEC-RAS River Analysis System: User's Manual. HEC-RAS User Manual. Washington, DC. US Army Corps of Engineers. Hydrologic Engineering Center pp. 790.

XIONG Y. 2011. A dam break analysis using HEC-RAS. Journal of Water Resource and Protection. Vol. 3. No. 6 p. 370-379.

YAKTI B.P., ADITYAWAN M.B., FARID M., SURYADI Y., NugROHO J. HADIHARDAJA K.I. 2018. 2D modeling of flood propagation due to the failure of Way Ela Natural Dam. Water Resources Engineering and Management. MATEC Web of Conferences. Vol. 147 p. 1-5.

Yamani K., Hazzab A., SekKoum M., Toumi S. 2016. Mapping of vulnerability of flooded area in arid region. Case study: Area of Ghardaia-Algeria. Modeling Earth Systems and Environment. Vol. 2. Iss. 3 pp. 17.

\section{Abdelghani BEKHIRA, Mohammed HABI, Boutkhil MORSLI}

\section{Zarządzanie zagrożeniem powodziowym w aglomeracjach miejskich w strefach klimatu suchego z wykorzystaniem programów HEC-RAS i GIS: Przykład powodzi w mieście Bechar}

\section{STRESZCZENIE}

W ostatnich latach miasto Bechar w Algierii doświadczyło kilku ekstremalnych zjawisk powodziowych, np. w $2008 \mathrm{r}$. z przepływem $830 \mathrm{~m}^{3} \cdot \mathrm{s}^{-1}\left(h_{\text {wody }}=4 \mathrm{~m}, b=200 \mathrm{~m}\right)$ po wyjątkowo dużych opadach deszczu. Podobne powodzie wystąpily w latach 2012 i 2014. Problemem jest fakt, że miasto Bechar rozciąga się do brzegów Wadi Bechar, co stwarza poważne zagrożenie dla życia mieszkańców regionu. W niniejszej pracy oszacowano zagrożenie powodzią poprzez mapowanie ry- 
zyka. Ta metoda polega na określeniu wartości przepływu z okresem powtarzalności 25 lat $\left(Q_{25}=388,6 \mathrm{~m}^{3} \cdot \mathrm{s}^{-1}, h_{\text {wody }}=3,5 \mathrm{~m}\right.$, $\left.b=200 \mathrm{~m}, S_{\text {zagr. }}=55,35 \mathrm{ha}\right), 50$ lat $\left(Q_{50}=478,3 \mathrm{~m}^{3} \cdot \mathrm{s}^{-1}, h_{\text {wody }}=5 \mathrm{~m}, b=200 \mathrm{~m}, S_{\text {zagr. }}=66,48 \mathrm{ha}\right)$ i 100 lat $\left(Q_{100}=567,3 \mathrm{~m}^{3} \cdot \mathrm{s}^{-1}\right.$, $h_{\text {wody }}=7 \mathrm{~m}, b=200 \mathrm{~m}, S_{\text {zagr. }}=133 \mathrm{ha}$ ). Do mapowania zjawiska należy dostosować wartości przepływów z wykorzystaniem prawa Gumbela za pomocą programów komputerowych HEC-RAS, HEC-GeoRAS i ArcGIS. Niniejsza praca umożliwia określenie stref narażonych na ryzyko powodzi i ich klasyfikację w zależności od wysokości fali powodziowej.

Słowa kluczowe: mapowanie, powódź, strefy klimatu suchego, zasoby wodne, zmiany klimatyczne 